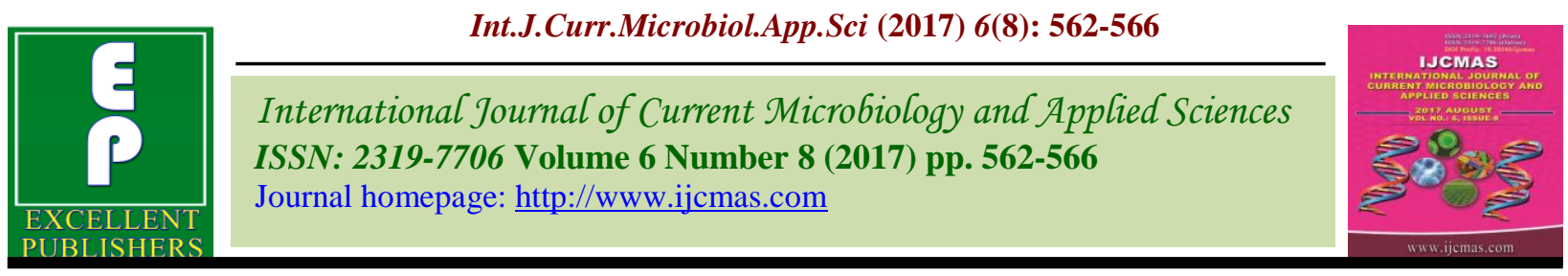

Original Research Article

https://doi.org/10.20546/ijcmas.2017.608.073

\title{
Effect of Inorganic and Organic Fertilizers on Yield and Economics of Broccoli (Brassica olerasia var. italica)
}

\author{
Priyanka Lodhi $^{1}{ }^{*}$, Devi Singh ${ }^{1}$ and Anupam Tiwari ${ }^{2}$ \\ ${ }^{1}$ Department of Horticulture, Sam Higginbottom Institute of Agriculture, Technology and \\ Sciences, Allahabad (U.P.), India- 211007 \\ ${ }^{2}$ Department of Horticulture, I.Ag.Sc., B.H.U., Varanasi- 221 005, India \\ *Corresponding author
}

\section{A B S T R A C T}

Keywords

Broccoli, Curd,

Economics,

Poultry manure,

Vermicompost.

Article Info

Accepted:

04 June 2017

Available Online:

10 August 2017
A field experiment was conducted during winters 2015-16 to study the effect of inorganic and organic fertilizers on yield and economics of broccoli cv. Green Magic. The experiment was laid out in Randomized Block Design with twelve treatments and three replications. Different doses of recommended dose of nitrogen (RDN), Farm yard manure (FYM), Poultry manure, Vermicompost and their combinations are used with all other cultural practices taken uniform. The maximum curd diameter $(15.37 \mathrm{~cm})$, weight of trimmed curd $(413.33 \mathrm{~g})$, curd yield per plot $(7.44 \mathrm{~kg})$ and curd yield $(14.16 \mathrm{t} / \mathrm{ha})$ were recorded in the plants treated with $50 \%$ recommended dose of nitrogen(RDN) $+16.6 \%$ farm yard manure $(\mathrm{FYM})+16.6 \%$ Vermicompost $+16.6 \%$ Poultry Manure. Economic returns of the same treatment were also found best in term of gross income, net returns and benefit-cost ratio.

\section{Introduction}

Broccoli (Brassica olerasia var. italica) is one of the important cool season vegetable of Brassicacae family (Swarup, 2012). It is a high value exotic vegetable and cultivated for its tender flowering head and the secondary heads $i$. $e$. spears. It was a rare cole crop in India but now it is gaining popularity in metropolitan cities, reputed hotels and restaurants (Maurya, 2008). Generally it can be classified into three distinct group viz., white purple and green, out of which green type is highly nutritious (Yoldas et al., 2008). Broccoli is rich source of vitamins, minerals and essential amino acids, also contains the compound glucoraphanin which have anticancerous properties (Swarup, 2012). It is either consumed raw as salad or cooked to prepare curries, soup and pickles. In the world market broccoli sold about 60 percent as frozen and remaining 40 percent as fresh. Now days, broccoli emerges as an important crop under protected cultivation during off season around metropolitans and tourist places (Swarup, 2012).

To increase the yield, plenty of chemical fertilizers along with a small quantity of organic once are being used by different workers which ultimately affects the health of soil as well as human (Meena et al., 2017). Due to excess use of chemical fertilizers a decline pattern is observed in soil fertility, 
therefore integrated nutrient management is an important demand of present era (Attigah et al., 2013). The main aim of integrated nutrient management is to cultivate a land in such a way that the soil should remain sustainable with maximum quality production of crop (Mishra et al., 2014). Manures provide a source of all necessary macro and micro-nutrients in available forms, thereby improving the physical and biological properties of the soil (Abou El-Magd et al., 2006).Considering the above factors, the present experiment was undertaken to determine the best inorganic and organic fertilizer combination for maximum yield and net profit in broccoli.

\section{Materials and Methods}

The present experiment was carried out during winter season of 2015-16 at the Vegetable Research Field, Department of Horticulture, Allahabad School of Agriculture, Sam Higginbottom Institute of Agriculture, Technology and Sciences, Allahabad, Uttar Pradesh. The experiment was laid out in randomized block design with twelve treatments and three replications. Broccoli cultivar Green Magic was taken as test crop. The treatments included $\mathrm{T}_{0}$ : recommended dose of NPK (120:80:80 kg /ha), $\mathrm{T}_{1}$ : Farmyard manure @ 20 t/ha, $\mathrm{T}_{2}$ :Vermicompost @ 10 t/ ha, $\mathrm{T}_{3}$ : Poultry manure @6 t/ha, T $: 33.3 \%$ FYM + 33.3\% Vermicompost $+33.3 \%$ Poultry manure, $\mathrm{T}_{5}$ : $50 \% \mathrm{RDN}+50 \% \mathrm{FYM}, \mathrm{T}_{6}: 50 \% \mathrm{RDN}+50 \%$ Vermicompost, $\mathrm{T}_{7}: 50 \%$ RDN $+50 \%$ Poultry manure, $\mathrm{T}_{8}: 50 \% \mathrm{RDN}+25 \% \mathrm{FYM}+25 \%$ Vermicompost, $\mathrm{T}_{9}: 50 \%$ RDN $+25 \%$ Vermicompost $+25 \%$ Poultry manure, $\mathrm{T}_{10}$ : $50 \%$ RDN $+25 \%$ FYM $+25 \%$ Poultry manure and $\mathrm{T}_{11}: 50 \% \mathrm{RDN}+16.6 \% \mathrm{FYM}+$ $16.6 \%$ Vermicompost $+16.6 \%$ Poultry Manure. The crop was raised with a spacing of $60 \mathrm{~cm} \times 50 \mathrm{~cm}$ and plot size of $3.5 \mathrm{~m} \times 1.5$ $\mathrm{m}$. Standard cultural practices recommended for Broccoli was followed uniformly for all the experimental plots. According to treatment details, organic manures (FYM, Poultry Manure and Vermicompost) were applied in plots one month before the transplanting of seedlings. Nitrogen, phosphorous and potassium were applied in the form of Urea, Diammonium Phosphate and Muriate of Potas. Before transplanting, half of nitrogen and full doses of phosphorous and potassium were applied in the plots and the crop was top dressed with remaining half dose of nitrogen in two splits after $4^{\text {th }}$ and $6^{\text {th }}$ week of transplanting. The observations like diameter of curd $(\mathrm{cm})$, weight of curd $(\mathrm{g})$, curd yield per plot $(\mathrm{kg})$ and curd yield (tonnes/ha) were recorded. Economics of the experiment was worked out on the basis of prevailing market prices of inputs and outputs. The data of the trial obtained were subjected to statistical analysis and the results were documented, analysed and presented in tabular form.

\section{Results and Discussion}

The presented data in table 1 is concerning with the yield attributes of broccoli as affected by different organic and inorganic fertilizers either alone or in combinations. Maximum curd diameter $(15.37 \mathrm{~cm})$ was recorded with Treatment $\mathrm{T}_{11}(50 \% \mathrm{RDN}+$ $16.6 \%$ FYM + $16.6 \%$ Vermicompost +16.6 $\%$ Poultry Manure) followed by $14.18 \mathrm{~cm}$ with $\mathrm{T}_{10}(50 \% \mathrm{RDN}+25 \% \mathrm{FYM}+25 \%$ Poultry Manure) and the minimum (11.50 $\mathrm{cm})$ was recorded with $\mathrm{T}_{1}\left(20 \mathrm{t} \mathrm{ha}^{-1} \mathrm{FYM}\right)$. The combined application of optimum levels of inorganic fertilizers and Organic fertilizers in deficient soil might have improved the physicochemical and biological characteristics of the growth medium. 
Table.1 Effect of inorganic and organic fertilizers on yield and economics of broccoli

\begin{tabular}{|c|c|c|c|c|c|c|c|c|c|}
\hline Treatments & $\begin{array}{l}\text { Diameter } \\
\text { of } \\
\text { curd }(\mathrm{cm})\end{array}$ & $\begin{array}{l}\text { Weight of } \\
\operatorname{curd}(\mathrm{g})\end{array}$ & $\begin{array}{c}\text { Curd } \\
\text { yield/Plot } \\
(\mathrm{kg})\end{array}$ & $\begin{array}{c}\text { Curd } \\
\text { yield(t/ha) }\end{array}$ & $\begin{array}{c}\text { Selling } \\
\text { Rate } \\
\left(\mathrm{Rst}^{-1}\right)\end{array}$ & $\begin{array}{c}\text { Gross } \\
\text { Return } \\
\left(\mathrm{Rs} \mathrm{ha}^{-1}\right)\end{array}$ & $\begin{array}{c}\text { Cost of } \\
\text { Cultivation } \\
\left(\mathrm{Rs} \mathrm{ha}^{-1}\right)\end{array}$ & $\begin{array}{l}\text { Net Return } \\
\left(\text { Rs ha }^{-1}\right)\end{array}$ & B:C Ratio \\
\hline $\mathrm{T}_{0}$ & 13.12 & 386.04 & 6.94 & 13.22 & 25,000 & 330000 & 85446 & 244554 & 3.80 \\
\hline $\mathrm{T}_{1}$ & 11.50 & 285.33 & 5.13 & 9.77 & 25,000 & 244250 & 125260 & 118990 & 1.94 \\
\hline $\mathrm{T}_{2}$ & 11.52 & 291.86 & 5.25 & 10.03 & 25,000 & 257500 & 107260 & 150240 & 2.40 \\
\hline $\mathrm{T}_{3}$ & 11.92 & 302.23 & 5.44 & 10.35 & 25,000 & 258750 & 89260 & 169490 & 2.89 \\
\hline $\mathrm{T}_{4}$ & 12.40 & 320.33 & 5.91 & 11.25 & 25,000 & 281250 & 107160 & 174090 & 2.62 \\
\hline $\mathrm{T}_{5}$ & 12.47 & 385.67 & 6.94 & 13.21 & 25,000 & 330250 & 105362 & 224888 & 3.13 \\
\hline $\mathrm{T}_{6}$ & 12.85 & 394.00 & 7.09 & 13.50 & 25,000 & 337500 & 96362 & 241138 & 3.50 \\
\hline $\mathrm{T}_{7}$ & 12.65 & 386.00 & 6.95 & 13.23 & 25,000 & 330750 & 87362 & 243388 & 3.78 \\
\hline $\mathrm{T}_{8}$ & 12.80 & 394.67 & 7.10 & 13.52 & 25,000 & 338000 & 100862 & 237138 & 3.35 \\
\hline $\mathrm{T}_{9}$ & 12.42 & 391.33 & 7.04 & 13.40 & 25,000 & 335000 & 91862 & 243138 & 3.64 \\
\hline $\mathrm{T}_{10}$ & 14.18 & 403.67 & 7.26 & 13.83 & 25,000 & 345750 & 96362 & 249388 & 3.58 \\
\hline $\mathrm{T}_{11}$ & 15.37 & 413.33 & 7.44 & 14.16 & 25,000 & 366500 & 96292 & 270208 & 3.81 \\
\hline $\begin{array}{l}\mathrm{CD}(\mathrm{P}= \\
0.05)\end{array}$ & 0.03 & 8.69 & 0.16 & 0.30 & & & & & \\
\hline
\end{tabular}


There increased the concentration of essential nutrients in soil solution resulted in steady uptake of major nutrients, sturdy plant growth and improvement of head weight and total yield. Kumar et al., (2013) and (Singh et al., 2010) also noted the similar findings in various cole crops.

Maximum weight of trimmed curd (413.33g) was recorded with Treatment $\mathrm{T}_{11}(50 \% \mathrm{RDN}$ $+16.6 \%$ FYM $+16.6 \%$ Vermicompost + $16.6 \%$ Poultry manure) followed by $403.67 \mathrm{~g}$ with $\mathrm{T}_{10}(50 \% \mathrm{RDN}+25 \% \mathrm{FYM}+25 \%$ Poultry manure) and the minimum $(285.33 \mathrm{~g})$ was recorded with $\mathrm{T}_{1}\left(20 \mathrm{t} \mathrm{ha}^{-1} \mathrm{FYM}\right)$. The increase in curd weight might be due to the more photosynthesis from a larger area of the leaves and the translocation of photosynthates to the sink which is ultimately the curd. The increase in the curd weight at this level might also be due to the increase in the length and width of the leaves, plant spread, curd diameter and curd depth. Shree et al., (2014) in cauliflower reported that maximum curd weight was observed in various combinations of organic and inorganic fertilizers.

Maximum curd yield per plot $(7.44 \mathrm{~kg})$ was recorded with Treatment $\mathrm{T}_{11}(50 \% \mathrm{RDN}+$ $16.6 \% \mathrm{FYM}+16.6 \%$ Vermicompost +16.6 $\%$ Poultry Manure) followed by $7.26 \mathrm{~kg}$ with $\mathrm{T}_{10}(50 \% \mathrm{RDN}+25 \% \mathrm{FYM}+25 \%$ Poultry Manure) and the minimum $(5.13 \mathrm{~kg})$ was recorded with $\mathrm{T}_{1}\left(20 \mathrm{t} \mathrm{ha}^{-1} \mathrm{FYM}\right)$. These results are in accordance with the findings of Singh (2000) in cabbage and Sharma (2000) in broccoli have reported that integration of organic and inorganic fertilizers synergistically increase the head yield over inorganic fertilizer alone. Maximum curd yield per hectare (14.16 t) was recorded with Treatment $\mathrm{T}_{11}(50 \% \mathrm{RDN}+16.6 \% \mathrm{FYM}+$ $16.6 \%$ Vermicompost $+16.6 \%$ Poultry Manure) followed by 13.83 tonnes with $\mathrm{T}_{10}$ $(50 \%$ RDN $+25 \%$ FYM $+25 \%$ Poultry Manure) and the minimum $(9.47 \mathrm{t})$ was recorded with $\mathrm{T}_{1}\left(20 \mathrm{t} \mathrm{ha}^{-1}\right)$. Maurya et al., (2008) also record highest values of yield related traits with application of Vermicompost and half dose of recommended fertilizers. These results are in close conformity with the finding of Devi et al., (2003) in Cabbage, Manivannan and Singh (2004) in Broccoli, and Wani et al., (2011) in Cauliflower.

The economics of different treatments viz., yield $\left(\mathrm{t} \mathrm{ha}^{-1}\right)$, cost of cultivation, gross return and benefit cost ratio has been worked out and presented in table 1. Maximum gross return $\left(3,66,500 \mathrm{Rs} \mathrm{ha}^{-1}\right)$, Maximum net return $\left(2,70,208 \mathrm{Rs} \mathrm{ha}^{-1}\right)$ and Maximum benefit cost ratio $(3.81: 1)$ were recorded with treatment $\mathrm{T}_{11}(50 \% \mathrm{RDN}+16.6 \% \mathrm{FYM}+$ $16.6 \%$ Vermicompost $+16.6 \%$ Poultry Manure) followed by $\mathrm{T}_{10}(50 \% \mathrm{RDN}+25 \%$ FYM $+25 \%$ Poultry Manure) whereas, the minimum was recorded with $\left(2,44,250 \mathrm{Rs} \mathrm{ha}^{-1}\right)$ $\mathrm{T}_{1}\left(24 \mathrm{t} \mathrm{ha}^{-1} \mathrm{FYM}\right)$. These results are found similar to USDA Economics, Statistics and Market Information System.

In conclusion, study revealed that the integration of organic and inorganic fertilizers had shown a marked effect in enhancing yield as well as productivity of broccoli with maximum net returns. On the basis of results, it could be concluded that the application of $50 \%$ recommended dose of nitrogen $+16.6 \% \mathrm{FYM}+16.6 \%$ Vermicompost $+16.6 \%$ Poultry Manure were best for higher yield with maximum profit. It can be recommended for commercial production of broccoli under Allahabad conditions of Uttar Pradesh.

\section{References}

Abou El-Magd, M.M., El-Bassiony, A.M. and Fawzy, Z.F. 2006. Effect of organic manure with or without chemical fertilizers on growth, yield and quality of some varieties of broccoli plants. J. Appl. 
Sci. Res., 2(10): 791-798.

Attigah, A.S., Asiedu, E.K., Agyarko, K. and Dapaah, H.K. 2013. Growth and yield of okra (Abelmoschus esculentus L.) as affected by organic and inorganic fertilizers. ARPN: J. Agri. Biol. Sci., 8(12): 766-770.

Devi, H.J., T.K. Maity and N.C. Paria. 2003. Effect of different sources of nitrogen on yield and economics of cabbage. Environ. Ecol., 21(4): 878-880.

Kumar, M., Das, B., Prasad, K.K. and Kumar, P. 2013. Effect of integrated nutrient management on growth and yield of broccoli (Brassica oleracea var. italica) under Jharkhand conditions. Veg. Sci., 40(1): 117-120.

Manivannan, M.I. and Singh, J.P. 2004. Effect of biofertlizers on the growth and yield of sprouting broccoli (Brassica oleracea var. italica Plank) under Allahabad agroclimatic condition. Bioved., 15(1/2): 33-36.

Maurya, A.K., Singh, M.P., Srivastava, B.K., Singh, Y.V., Singh, D.K., Singh, S. and Singh, P.K. 2008. Effect of organic manures and inorganic fertilizers on growth characters, yield and economics of sprouting broccoli cv. Fiesta. Indian J. Horticulture, 65(1): 116-118.

Meena, V.K., Dubey, A.K., Jain, V.K, Tiwari, A. and Negi P. 2017. Effect of plant growth promoters on flowering and fruiting attributes of okra [Abelmoschus esculentus (L.) Moench]. Crop Res., 52(1, 2 \& 3): 37-40

Mishra, P.P., Das, A.K. and Mishra, N. 2014. Effect of integrated nutrient management on yield, quality and economics of knolkhol (Brassica oleracea L. cv.

\section{How to cite this article:}

Priyanka Lodhi, Devi Singh and Anupam Tiwari. 2017. Effect of Inorganic and Organic Fertilizers on Yield and Economics of Broccoli (Brassica olerasia var. italica). Int.J.Curr.Microbiol.App.Sci. 6(8): 562-566. doi: https://doi.org/10.20546/ijcmas.2017.608.073 gongylodes). Asian J. Horticulture, 9(2): 382-385.

Sharma, K.C. 2000. Influence of integrated nutrient management on yield and economics in broccoli (Brassica oleracea L. var italica Plenck) under cold temperate conditions. Veg. Sci., 27(1): 62-63.

Shree, S., Singh, V.K., and Kumar, R. 2014. Effect of integrated nutrient management on yield and quality of cauliflower (Brassica oleracea var. botrytis L.). The Bioscan, 9(3): 1053-1058.

Singh, A.K., and Singh, A. 2000. Influence of nitrogen and potassium on growth and head yield of broccoli (Brassica oleracea L.var. italica) under low hills subtropical condition of H.P. Veg. Sci., 27(1): 99 100.

Singh, P.K. and Pandey, M. 2010. Study the effect of integrated nutrient management on yield and nutrient uptake in cabbage. Indian J. Hill Farming, 23(2): 39-41.

Swarup, V. 2012. Vegetable science and technology in India. Kalayani Publishers, New Delhi, pp 370-371.

Wani, A.J., Raj Narayan, Ahmed, N., Singh, A.K., Chattoo, M.A., and Narayan, S. 2011. Influence of organic and inorganic sources of nutrients on growth, yield and quality of cauliflower (Brassica oleracea var botrytis L.). Environ. Ecol., 29(4): 1941-1947.

Yoldas, F., Ceylan, S., Yagmur, B. and Mordogan, N. 2008. Effects of nitrogen fertilizer on yield quality and nutrient content in broccoli. J. Plant Nutri., 31(7): 1333-1343. 